\title{
Persistent Sodium Current in Layer 5 Neocortical Neurons Is Primarily Generated in the Proximal Axon
}

\author{
Nadav Astman, Michael J. Gutnick, and Ilya A. Fleidervish \\ Koret School of Veterinary Medicine, The Hebrew University of Jerusalem, Rehovot 76100, Israel
}

In addition to the well described fast-inactivating component of the $\mathrm{Na}^{+}$current $\left[\operatorname{transient~} \mathrm{Na}^{+} \operatorname{current}\left(I_{\mathrm{NaT}}\right)\right]$, neocortical neurons also exhibit a low-voltage-activated, slowly inactivating "persistent" $\mathrm{Na}^{+}$current $\left(I_{\mathrm{NaP}}\right)$, which plays a role in determining neuronal excitability and synaptic integration. We investigated the $\mathrm{Na}^{+}$channels responsible for $I_{\mathrm{NaP}}$ in layer 5 pyramidal cells using cell-attached and whole-cell recordings in neocortical slices. In simultaneous cell-attached and whole-cell somatic recordings, no persistent $\mathrm{Na}^{+}$channel activity was detected at potentials at which whole-cell $I_{\mathrm{NaP}}$ operates. Detailed kinetic analysis of late $\mathrm{Na}^{+}$channel activity in cell-attached patches at $36^{\circ} \mathrm{C}$ revealed that somatic $\mathrm{Na}^{+}$channels do not demonstrate "modal gating" behavior and that the probability of single late openings is extremely low $\left(<1.4 \times 10^{-4}\right.$ or $<0.02 \%$ of maximal open probability of $\left.I_{\mathrm{NaT}}\right)$. Ensemble averages of these currents did not reveal a sustained component whose amplitude and voltage dependence could account for $I_{\mathrm{NaP}}$ as seen in whole-cell recordings. Local application of TTX to the axon blocked somatically recorded $I_{\mathrm{NaP}}$, whereas somatic and dendritic application had little or no effect. Finally, simultaneous current-clamp recordings from soma and apical dendrite revealed that $\mathrm{Na}^{+}$plateau potentials originate closer to the axon. Our data indicate that the primary source of $I_{\mathrm{NaP}}$ is in the spike initiation zone in the proximal axon. The focal axonal presence of regenerative subthreshold conductance with voltage and time dependence optimal to manipulate integration of synaptic input, spike threshold, and the pattern of repetitive firing provides the layer 5 pyramidal neuron with a mechanism for dynamic control of its gain.

Key words: sodium channel; persistent sodium current; axon; excitability; layer 5 pyramidal neuron; neocortex

\section{Introduction}

Somata and processes of central neurons contain an inhomogeneously distributed mixture of molecularly distinct voltage-gated $\mathrm{Na}^{+}$channels (Migliore and Shepherd, 2002; Yu and Catterall, 2003). Fast-inactivating, transient current through these channels plays a central role in initiation and propagation of action potentials (Hodgkin and Huxley, 1952; Stuart and Sakmann, 1994). In addition, there is a more slowly inactivating, TTXsensitive, "persistent" $\mathrm{Na}^{+}$current $\left(I_{\mathrm{NaP}}\right.$ ) (Chandler and Meves, 1966; Gutnick and Crill, 1995; Crill, 1996), the functional importance of which relates to dynamic control of the "gain" (Chance et al., 2002) of the neuronal input-output relationship. $I_{\mathrm{NaP}}$ operates in the subthreshold voltage range, where other large, voltagegated conductances are not active (Crill, 1996). It may thus influence both synaptic integration properties of a neuron and the character of its spike output. A precise understanding of the role of $I_{\mathrm{NaP}}$ requires knowledge of the distribution and the biophysical properties of the ion channels that generate it.

A variety of potential mechanisms are available that might lead different regions of a given neuron to display different amounts of $I_{\mathrm{NaP}}$. These include regional differences in $\mathrm{Na}^{+}$chan-

Received Nov. 16, 2005; revised Feb. 13, 2006; accepted Feb. 13, 2006.

This work was supported by Grant 2003082 from the United States-Israel Binational Science Foundation, Jerusalem, Israel.

Correspondence should be addressed to llya A. Fleidervish, Koret School of Veterinary Medicine, The Hebrew University of Jerusalem, P.0. Box 12, Rehovot 76100, Israel. E-mail: fleider@agri.huji.ac.il.

DOI:10.1523/JNEUROSCI.4907-05.2006

Copyright $\odot 2006$ Society for Neuroscience $\quad$ 0270-6474/06/263465-09\$15.00/0 nel density (Catterall, 1981; Migliore and Shepherd, 2002), in channel subunit composition (Westenbroek et al., 1989; Smith et al., 1998; Gong et al., 1999; Caldwell et al., 2000), regional differences in the relationship between the $\mathrm{Na}^{+}$channel and intracellular and extracellular matrices (Srinivasan et al., 1998; Qu et al., 1999), and regional differences in neuromodulation (Cantrell and Catterall, 2001). Functional evidence suggests a difference in the propensity of different neuronal compartments to generate $I_{\mathrm{NaP}}$. Thus, in simultaneous somatic and dendritic recordings from neocortical layer 5 pyramidal neuron, Stuart and Sakmann (1995) found that EPSPs were amplified by $I_{\mathrm{NaP}}$ that was generated by $\mathrm{Na}^{+}$channels located not in the dendrites, but rather, near the soma and axon. Similar findings have also been reported for pyramidal neurons of CA1 area of hippocampus (Andreasen and Lambert, 1999; Yue et al., 2005). On the other hand, evidence for dendritic $I_{\mathrm{NaP}}$ has also been reported (Lipowsky et al., 1996; Mittmann et al., 1997; Magistretti et al., 1999b).

Previous studies of the relationship between $\mathrm{Na}^{+}$channels and $I_{\mathrm{NaP}}$ have all involved experiments in enzymatically isolated neurons (Alzheimer et al., 1993b; Magistretti et al., 1999b; Taddese and Bean, 2002) or in heterologous systems (Smith et al., 1998; Cummins et al., 2001; Lossin et al., 2002; Mantegazza et al., 2005; Rush et al., 2005). In this study, we investigated $I_{\mathrm{NaP}}$ and $\mathrm{Na}^{+}$channel activities in layer 5 pyramidal neurons in slices maintained at physiological temperature. We report that the somatic and dendritic $\mathrm{Na}^{+}$channels play a minimal role in generation of $I_{\mathrm{NaP}}$, which is almost entirely generated by axonal $\mathrm{Na}^{+}$ channels. 


\section{Materials and Methods}

Slice preparation and maintenance. Experiments were performed in coronal slices of somatosensory cortex of postnatal day 14 (P14) to P24 CD-1 mice and P14-P30 Wistar rats, using procedures that are standard in our laboratory (Fleidervish et al., 1998). Animals of either sex were deeply anesthetized with Nembutal $\left(60 \mathrm{mg} \cdot \mathrm{kg}^{-1}\right)$, killed by decapitation, and their brains were rapidly removed and placed in cold $\left(6^{\circ} \mathrm{C}\right)$, oxygenated $\left(95 \% \mathrm{O}_{2}-5 \% \mathrm{CO}_{2}\right)$ artificial CSF (aCSF). Coronal slices $(300 \mu \mathrm{m})$ from a region corresponding to the primary somatosensory cortex were cut on a vibratome (Series 1000; Pelco International, Redding, CA) and placed in a holding chamber containing aCSF at room temperature; they were transferred to a recording chamber after $>1 \mathrm{~h}$ of incubation.

Patch-clamp recording. Whole-cell or cell-attached recordings from layer 5 neurons were either made blindly (Hamill et al., 1981; Blanton et al., 1989) or under infrared differential interference contrast (IR-DIC) microscopic control (Stuart et al., 1993). For blind recording, the slices were maintained in a small $(300 \mu \mathrm{l})$ interface-type recording chamber (Haas et al., 1979); for visually controlled recording, slices were held submerged in a chamber on the fixed stage of an Axioskop FS microscope (Carl Zeiss, Oberkochen, Germany). Single $\mathrm{Na}^{+}$channel openings were recorded in cell-attached configuration, and whole-cell current was recorded in whole-cell configuration using an Axopatch 200A or Axopatch 200B amplifier (Molecular Devices, Foster City, CA). Simultaneous current-clamp voltage recordings from the soma and an apical dendrite in whole-cell configuration were obtained using an Axoclamp-2B amplifier in bridge mode and Axopatch 200B amplifier in fast current-clamp mode. Simultaneous whole-cell and cell-attached recordings were obtained from the soma using an Axoclamp-2B amplifier in bridge mode and Axopatch 200B amplifier in voltage-clamp mode. Patch pipettes were manufactured from thick-walled borosilicate glass capillaries (outer diameter, $1.5 \mathrm{~mm}$; Hilgenberg, Malsfeld, Germany) and had resistances of 1.5-3.5 M $\Omega$ for somatic recordings and 7-9 $\mathrm{M} \Omega$ for dendritic recordings. For cell-attached recordings, pipettes were coated to within $\sim 100$ $\mu \mathrm{m}$ of the tip with Sylgard (Dow Corning, Midland, MI). All recordings were made at $36 \pm 1^{\circ} \mathrm{C}$.

Command voltage protocols were generated and single-channel data were acquired on-line with a Digidata $1320 \mathrm{~A}$ analog-to-digital interface. Data were low-pass filtered at $2-5 \mathrm{kHz}(-3 \mathrm{~dB}$, four-pole Bessel filter) and digitized at $10-20 \mathrm{kHz}$. For $\mathrm{Na}^{+}$channel recordings, capacitive and leak currents were reduced before data acquisition using the built-in circuits of the amplifier. Null traces for digital subtraction of remaining capacitative and leak current components were produced by stepping from a depolarized membrane potential, at which all $\mathrm{Na}^{+}$channels in the patch were inactivated. For simultaneous whole-cell and cell-attached recordings, null traces were produced by holding the patch at depolarizing voltage while applying the same current command through the whole-cell pipette. Before digital subtraction, the traces were aligned at half-amplitude of an action potential upstroke. For whole-cell voltageclamp recording, care was taken to maintain membrane access resistance as low as possible (usually $3-4 \mathrm{M} \Omega$ and always $<10 \mathrm{M} \Omega$ ); series resistance was $80 \%$ compensated using the built-in circuitry of the amplifier. Data were low-pass filtered at $2 \mathrm{kHz}(-3 \mathrm{~dB}$, four-pole Bessel filter) and sampled at $5-10 \mathrm{kHz}$ digitalization frequency. For whole-cell currentclamp recordings, data were low-pass filtered at $10 \mathrm{kHz}(-3 \mathrm{~dB}$, singlepole Bessel filter), stored on videotape, and digitized off-line at up to $20 \mathrm{kHz}$.

Apparent cell capacitance was estimated from recordings of capacitive current elicited by $40 \mathrm{~ms}, 10 \mathrm{mV}$ step hyperpolarizations from a holding potential of $-70 \mathrm{mV}$. Pipette capacitive currents were nulled before break-in. In some neurons, apparent cell capacitance was estimated in current-clamp recordings by applying small hyperpolarizing pulses and determining the time constant and the amplitude of the resulting voltage deflection.

The aCSF contained the following (in $\mathrm{mm}$ ): $124 \mathrm{NaCl}, 3 \mathrm{KCl}, 2 \mathrm{CaCl}_{2}$, $2 \mathrm{MgSO}_{4}, 1.25 \mathrm{NaH}_{2} \mathrm{PO}_{4}, 26 \mathrm{NaHCO}_{3}$, and 10 glucose, $\mathrm{pH} 7.3$ at $37^{\circ} \mathrm{C}$ when bubbled with a $95 \% \mathrm{O}_{2}-5 \% \mathrm{CO}_{2}$ mixture. The pipette solution for $\mathrm{Na}^{+}$channel experiments contained the following (in mM): $130 \mathrm{NaCl}, 3$ $\mathrm{KCl}, 2 \mathrm{CaCl}_{2}, 2 \mathrm{MgCl}_{2} 10$ glucose, 4 tetraethylammonium chloride, 1 4-AP, and 10 HEPES (sodium salt), pH 7.3. The pipette solution for
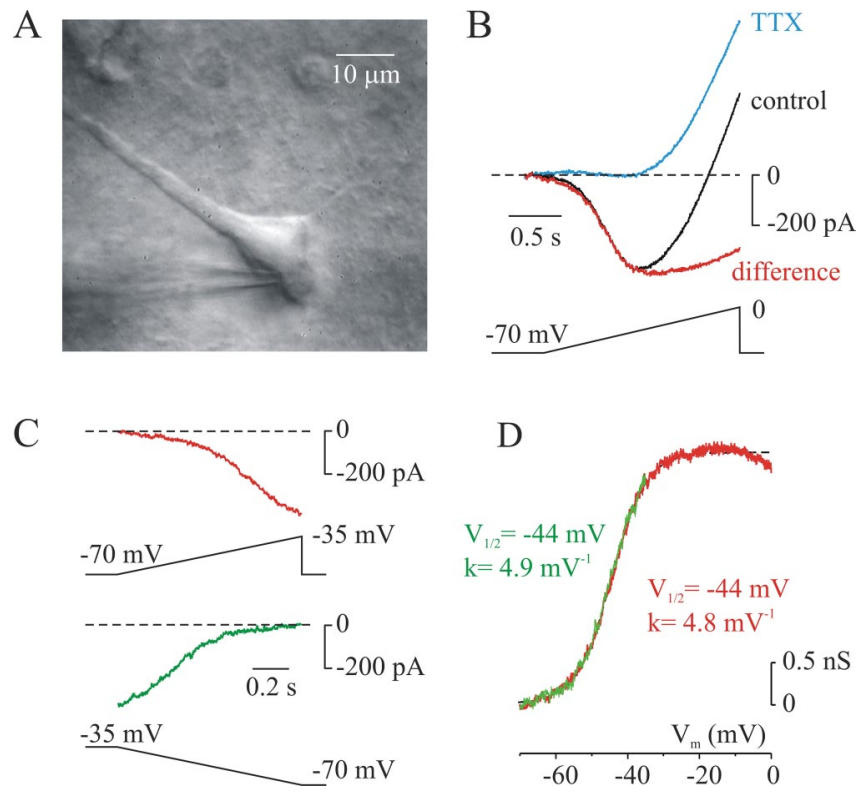

Figure 1. Properties of $I_{\mathrm{NaP}}$ elicited in layer 5 pyramidal neurons by slow voltage ramps. $\boldsymbol{A}$, IR-DIC image of a typical, visually identified layer 5 pyramidal cell in $300-\mu \mathrm{m}$-thick coronal slice of the neocortex. $\boldsymbol{B}$, Black trace, Instantaneous $/-V$ curve during a slow $(35 \mathrm{mV} / \mathrm{s}$ ) voltage ramp from -70 to $0 \mathrm{mV}$ (access resistance, $5 \mathrm{M} \Omega$; linear leak current subtracted). $\mathrm{K}^{+}$currents were blocked by using $\mathrm{Cs}^{+}$as the main intracellular monovalent cation, and $\mathrm{Ca}^{2+}$ currents were blocked by adding $200 \mu \mathrm{m} \mathrm{Cd}{ }^{2+}$ to the bath. Blue trace, Instantaneous I-V curve in the presence of TTX $\left(10^{-6} \mathrm{M}\right)$. Note that within the voltage range of -70 to $-35 \mathrm{mV}$, virtually all voltage-dependent conductances are blocked. $I_{\text {cat }}$ activates at potentials more positive than $-35 \mathrm{mV}$. Digital subtraction of traces before and after TTX application yields the instantaneous $I-V$ curve of $I_{\mathrm{NaP}}$ (red trace). C, Activation of $I_{\mathrm{NaP}}$ is not dependent on polarity of the voltage ramp. TTX-sensitive current has similar amplitude and voltage dependence during the depolarizing (top) and hyperpolarizing (bottom) voltage ramps. During the interval between the ramps, the membrane was held at $-70 \mathrm{mV}$. Before hyperpolarizing ramp, the membrane potential was stepped and held at $-35 \mathrm{mV}$ for $200 \mathrm{~ms}$. D, Conductance transform of $I_{\text {NaP }}$ elicited by depolarizing (red) and hyperpolarizing (green) ramps reveals that half-activation voltage and activation steepness factor are similar and they do not depend on direction of voltage change.

whole-cell voltage-clamp experiments contained (in $\mathrm{mm}$ ): $135 \mathrm{CsCl}, 2$ $\mathrm{MgCl}_{2}$, and 10 HEPES (cesium salt), $\mathrm{pH}$ 7.25. The pipette solution for whole-cell current-clamp experiments contained (in mM): 130 Cs gluconate, $6 \mathrm{CsCl}, 2 \mathrm{MgCl}_{2}$, and 10 HEPES (cesium salt), pH 7.25. TTX $(0.1-1 \mu \mathrm{M})$ was either added to the bath solution or puff-applied (5-10 $\mathrm{ms}, 20$ psi pressure pulses) through the patch pipette. All chemicals were obtained from Sigma (St. Louis, MO).

Data analysis. Data averaging, digital subtraction of null traces, and current peak detection were made using pClamp 9.0 (Molecular Devices) and Serf 1.78 software kindly adjusted to fit our needs by Dr. J. de Weille (Institut de Pharmacologie Cellulaire et Moleculaire, Valbonne, France). Data were fitted using Origin 6.0 (OriginLab, Northampton, MA). If not otherwise noted, values are given as mean $\pm \mathrm{SD}$. For statistical analysis, Student's $t$ test was performed.

\section{Results}

\section{Whole-cell persistent $\mathrm{Na}^{+}$current in layer 5 pyramidal neurons}

Figure 1 illustrates the properties of whole-cell $I_{\mathrm{NaP}}$ elicited by slow $(35 \mathrm{mV} / \mathrm{s})$ depolarizing voltage ramps in visually identified layer 5 pyramidal neurons (Fig. $1 A$ ) with $\mathrm{K}^{+}$and $\mathrm{Ca}^{2+}$ conductances blocked pharmacologically. To ascertain that the current generated by the ramp was indeed persistent, rather than reflecting very slow inactivation of transient $\mathrm{Na}^{+}$current $\left(I_{\mathrm{NaT}}\right)$ (Cummins et al., 2001), the rising rate of the ramps was adjusted to entirely inactivate even the "slowest" known transient $\mathrm{Na}^{+}$chan- 
nels (Cummins et al., 2001) while causing minimal slow inactivation of $I_{\mathrm{NaP}}$ (Fleidervish and Gutnick, 1996). As shown previously (Alzheimer et al., 1993a; Fleidervish and Gutnick, 1996), current was inward from around $-65 \mathrm{mV}$, reflecting $I_{\mathrm{NaP}}$ activation. At potentials more positive than $-35 \mathrm{mV}, I_{\mathrm{NaP}}$ was superimposed on a large outward cationic current, cationic current $\left(I_{\text {cat }}\right)$ (Alzheimer, 1994; Fleidervish and Gutnick, 1996). Digital subtraction of traces in the absence and presence of TTX yielded an instantaneous $I-V$ curve for $I_{\mathrm{NaP}}$, which peaked at voltages between -30 and $-20 \mathrm{mV}$ (Fig. $1 B$ ).

Additional evidence against contamination by $I_{\mathrm{NaT}}$ was obtained in five neurons by comparing currents elicited by depolarizing and hyperpolarizing voltage ramps. As illustrated in Figure $1, C$ and $D$, the amplitudes and voltage dependences of TTXsubtracted currents evoked by ramps of opposite polarity were not different, although the hyperpolarizing ramp was preceded by a $200 \mathrm{~ms}$ step to $-35 \mathrm{mV}$ to completely inactivate transient $I_{\mathrm{NaT}}$. Thus, for eight neurons, the $I_{\mathrm{NaP}}$ magnitude at $-35 \mathrm{mV}$ for hyperpolarizing ramps was $311 \pm 48 \mathrm{pA}$, half activation voltage was $-43 \pm 0.9 \mathrm{mV}$, and maximal steepness of the activation curve was $4.6 \pm 0.2 \mathrm{mV}^{-1}$, whereas for depolarizing ramps, these values were $313 \pm 47 \mathrm{pA},-41 \pm 1.2 \mathrm{mV}$, and $4.6 \pm 0.1 \mathrm{mV}^{-1}$, respectively ( $p>0.05$, paired Student's $t$ test).

Although the maximum amplitude of $I_{\mathrm{NaP}}$ in slices varied from cell to cell over a fairly wide range $(8-1600 \mathrm{pA} ; n=177)$, the median was $385 \mathrm{pA}$, which is significantly higher than values reported for acutely dissociated neurons (Alzheimer et al., 1993a; Hammarstrom and Gage, 1999; Taddese and Bean, 2002) or for non-neural mammalian cells expressing human neuronal $\mathrm{Na}^{+}$ channels (Lossin et al., 2002). These rarely exceed 100 pA. At first, we thought to attribute the difference between experimental preparations to the fact that much of the dendritic membrane, which has been shown to possess $\mathrm{Na}^{+}$channels (Huguenard et al., 1989; Stuart and Sakmann, 1994), remains intact in the brain slice. This conclusion seemed to be supported by the finding that the apparent $I_{\mathrm{NaP}}$ density calculated for the 67 neurons in which capacitance was measured (see Materials and Methods) was 0.3$14.3 \mathrm{pA} / \mathrm{pF}$ (median, $1.9 \mathrm{pA} / \mathrm{pF}$ ), which is comparable with or smaller than values in acutely dissociated cells (Alzheimer et al., 1993a; Hammarstrom and Gage, 1998). The calculation, however, is based on the assumption that channels responsible for $I_{\mathrm{NaP}}$ are homogenously distributed throughout the neuron; in the next series of experiments, we found this assumption to be wrong.

\section{Somatic $\mathrm{Na}^{+}$channels do not open at subthreshold voltages}

Because the functionally relevant consequences of $I_{\mathrm{NaP}}$ are primarily related to its activation at membrane potentials just below the spike threshold (Crill, 1996), we looked for somatic $\mathrm{Na}^{+}$ channel late openings in this voltage range. This could not be accomplished with channel recordings alone because the absolute value of the membrane potential is unknown and varies from cell to cell (Fleidervish et al., 1996, 1998). Therefore, while one pipette in cell-attached configuration recorded from $\mathrm{Na}^{+}$channels, an additional whole-cell pipette in the same neuron was used to record membrane potential and inject current (Fig. 2).

$\mathrm{Na}^{+}$channels in cell-attached patches were identified on the basis of their characteristic voltage dependence and conductance, as described in detail by Fleidervish et al. (1996). Briefly, $\mathrm{Na}^{+}$ channel openings first appeared at test pulse amplitudes between $V_{\mathrm{r}}+10$ and $V_{\mathrm{r}}+25 \mathrm{mV}$, and a progressive increase in test potential amplitude caused openings to cluster at the beginning of the pulse and late openings to become rarer. Slope conductance, as determined from a linear fit to the $I-V$ curve of the single
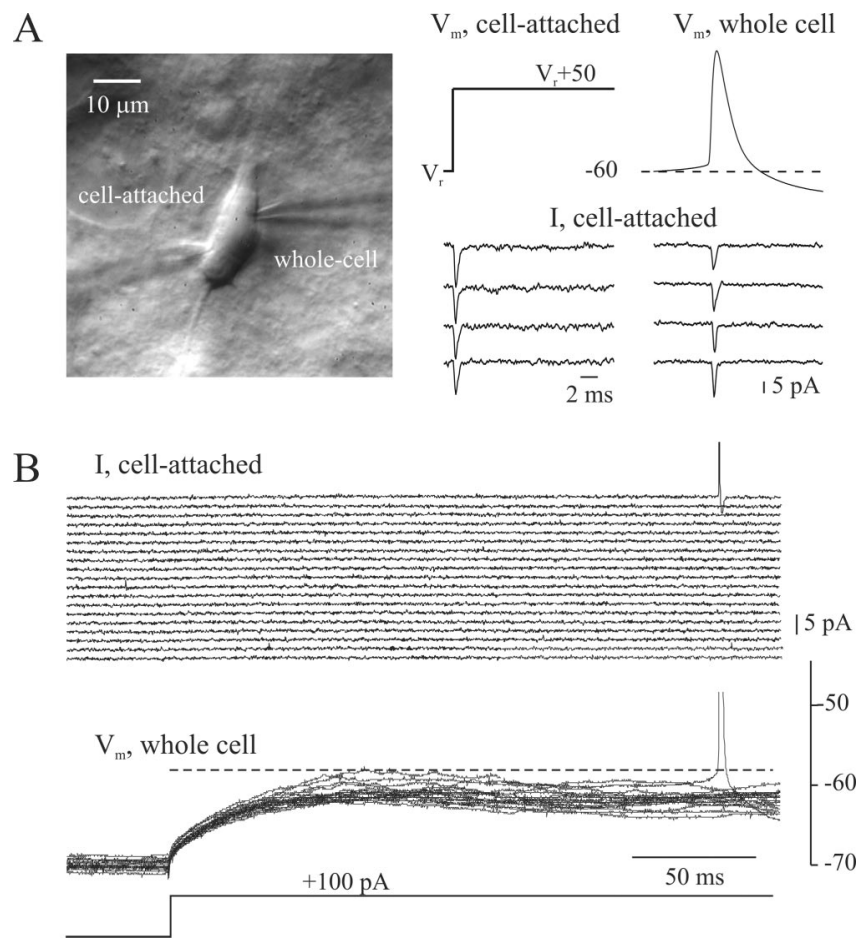

Figure 2. Somatic $\mathrm{Na}^{+}$channels do not open at subthreshold voltages. $\boldsymbol{A}$, Left, IR-DIC image illustrating simultaneous whole-cell, cell-attached recording from layer 5 pyramidal cell. Middle, Transient openings of $\mathrm{Na}^{+}$channels elicited by 40 ms depolarizing voltage pulses from $V_{r}$ to $V_{r}+50 \mathrm{mV}$ applied to the patch pipette. Right, Superimposed, Upstroke-aligned action potentials elicited by applying suprathreshold current pulse through whole-cell pipette and capacitance- and leak-subtracted sweeps of transient $\mathrm{Na}^{+}$channels openings elicited by these action potentials and recorded via the cell-attached pipette. The patch contained 28 channels. $\boldsymbol{B}$, In the same recording, no channel openings were detected when the cell was depolarized by 250-ms-long current steps to the subthreshold potentials at which $I_{\mathrm{NaP}}$ begins to operates. Shown are 20 whole-cell current (bottom) and voltage (middle) sweeps along with the corresponding patch current traces (top).

open channel in the range of $V_{\mathrm{r}}+20$ to $V_{\mathrm{r}}+70 \mathrm{mV}$, was $15 \pm 2$ pS; the extrapolated reversal potential was $V_{\mathrm{r}}+156 \pm 12 \mathrm{mV}$ $(n=5)$. Assuming that $V_{\mathrm{r}}$ is near $-77 \mathrm{mV}$ (Fleidervish et al., 1996, 1998), we estimate from the Nernst equation an internal $\mathrm{Na}^{+}$activity of $\sim 7 \mathrm{~mm}$.

As illustrated in Figure $2 \mathrm{~A}$, depolarizing voltage pulses applied to the patch pipette and action potentials elicited by suprathreshold current steps were associated with transient $\mathrm{Na}^{+}$ channel openings. However, depolarization of the membrane to voltages just below threshold elicited no detectible $\mathrm{Na}^{+}$channel openings ( $n=500$ trials) (Fig. 2 B). Quantitative evaluation of the open probability of a single $\mathrm{Na}^{+}$channel at subthreshold voltages shows that it is negligible, although some $I_{\mathrm{NaP}}$ is generated somewhere in the neuron at this voltage (Brown et al., 1994). The neuron in Figure 2 is representative of six cells in which we systematically sought late openings with prolonged, subthreshold pulses. Because no $\mathrm{Na}^{+}$channel openings were detected in 500, $250 \mathrm{~ms}$ depolarizing pulses, the ratio of the minimal duration of a detectable opening event ( $1 \mathrm{~ms}$ ) to the total duration of the subthreshold depolarization (100 s), normalized to the number of channels in the patch $(N=28$ in the cell in Fig. 2 ; see below), gave an upper limit of the open probability of $<10^{-6}$ per channel.

Probability of late $\mathrm{Na}^{+}$channel openings in somatic patches To determine whether probability of late openings $\left(P_{\mathrm{o}}\right)$ of somatic $\mathrm{Na}^{+}$channels could account for whole-cell $I_{\mathrm{NaP}}$, we re- 
corded $\mathrm{Na}^{+}$channel currents from somata of 19 neurons. Individual openings were clearly resolvable with a filter bandwidth open to $2-3.5 \mathrm{kHz}$ (see Fig. 4). All patches contained multiple channels, as indicated by the appearance of overlapping opening events during the peak of the currents elicited by depolarizing steps. Although it would be possible to directly assess $P_{\mathrm{o}}$ for late openings of an individual channel if the patch contained only one $\mathrm{Na}^{+}$channel, in our multichannel patches, the late $\mathrm{Na}^{+}$channel activity had to be normalized to the number of channels, $N$, a value which had to be explicitly determined.

In most previous studies (Alzheimer et al., 1993b; Magistretti et al., 1999a), the number of $\mathrm{Na}^{+}$channels has been estimated by determining the maximal current amplitude in a long series of repetitive depolarizations divided by the unitary channel current $i$. Considering that the peak $P_{\mathrm{o}}$ value is low even at depolarizing voltages, as evident from significant trialto-trial fluctuations of $\mathrm{Na}^{+}$currents during repetitive depolarizations (Fig. $3 A, B$ ), this method can only provide a lower limit for $N$. We therefore used two additional methods to estimate $N$. Figure $3 A$ (right) shows measurements of $\mathrm{Na}^{+}$current peak amplitudes during a series of 750 depolarizing steps from $V_{\mathrm{r}}-40$ to $V_{\mathrm{r}}+60 \mathrm{mV}$. Assuming that all $\mathrm{Na}^{+}$channels within the patch are independent and have uniform conductance and open probability, $N$ and peak $P_{\mathrm{o}}$ could be given as follows (Kimitsuki et al., 1990):

$$
\begin{gathered}
N=\frac{I_{\text {peak }}}{i P_{\mathrm{o}}} \\
P_{\mathrm{o}}=1-\frac{\sigma_{\text {peak }}^{2}}{i I_{\text {peak }}},
\end{gathered}
$$

where $I_{\text {peak }}$ is mean $I_{\mathrm{Na}}$ value at the peak, and $\sigma_{\text {peak }}^{2}$ is peak $I_{\mathrm{Na}}$ variance. Substitution of the values experimentally measured for the patch of Figure $3, I_{\text {peak }}=-8.15 \mathrm{pA}, \sigma_{\text {peak }}^{2}=3.41 \mathrm{pA}^{2}$, and $i=$ $1.37 \mathrm{pA}$, to these equations yielded $P_{\mathrm{o}}=0.69$ and $N=8.7$ channels.

An additional approach to estimate $N$ is to analyze the variance to current ratio during the current decay (Neher and Stevens, 1977; Kimitsuki et al., 1990). Thus, if the values of $I(t)$ and $\sigma^{2}(t)$ at time $t$ after the onset of depolarization are given as follows:

$$
\begin{gathered}
I(t)=P_{\mathrm{o}}(t) i N \\
\sigma^{2}(t)=P_{\mathrm{o}}(t)\left[1-P_{\mathrm{o}}(t)\right] i^{2} N,
\end{gathered}
$$

the relationship between the variance and the current will be the following:

$$
\frac{\sigma^{2}(t)}{I(t)}=\left[1-P_{\mathrm{o}}(t)\right] i=i-\frac{I(t)}{N} .
$$
traces. Error bars represent SD.
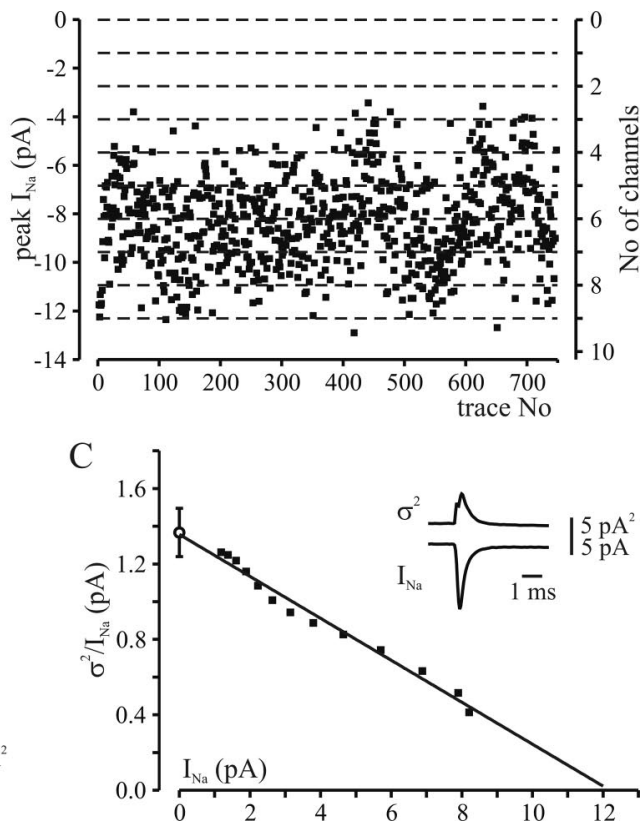

Figure 3. Evaluation of the number of $\mathrm{Na}^{+}$channels in multichannel cell-attached patch recordings. A, Analysis of peak current variability. Left, Fluctuations in $\mathrm{Na}^{+}$channel current peak amplitudes during repetitive depolarizations. Seven consecu列 plied every $200 \mathrm{~ms}$. Recording at $36 \pm 1{ }^{\circ} \mathrm{C}$. Rias $V_{r}-40 \mathrm{mV}$, and the 5-ms-long depolarizing steps to $V_{r}+60 \mathrm{mV}$ were individual current traces as in $\boldsymbol{A}$ (thick line), superimposed on the ensemble average of 750 sweeps (mean current $[(t)]$ thin line). Middle column, Differences between each individual trace and the mean current. Right column, The squares of e differences. The ensemble average of 750 such traces represents the variance of the current, $\sigma^{2}(t)(\boldsymbol{C}$, inset). $\boldsymbol{C}$, The ratio 政 tively. The open circle is the mean unitary current amplitude as measured directly $(1.36 \pm 0.01 \mathrm{pA} ; n=185)$. Inset, $\sigma^{2}(t)$ and $/(t)$

The mean current $I(t)$ was calculated by averaging 750 consecutive $\mathrm{Na}^{+}$channel sweeps. $\sigma^{2}(t)$ was calculated as the average of the squares of the differences between each individual current trace and the mean current (Fig. $3 B$ ). In Figure $3 C$, the variance to current ratio, $\sigma^{2}(t) / I(t)$, was plotted as a function of the current, $I(t)$. The relationship was linear, as predicted by Equation 5 . The unitary single-channel current amplitude, $i$, estimated from the $y$-intercept of the extrapolated linear regression line [e.g., at $I(t)=0$ ], was $1.36 \mathrm{pA}$, which is near the $i$ value directly measured from well resolved single channel events (1.37 pA). The $x$-intercept of the extrapolated linear regression line [the imaginary state that would occur when all channels are open; $P_{\mathrm{o}}(t)=1$, $\sigma^{2}(t) / I(t)=0$ and $\left.I(t)=i N\right]$ was $12.2 \mathrm{pA}$. Division of this value by $i$ gave $N=9$ channels. Good agreement between the values of $N$ determined by peak current fluctuation analysis and by current decay fluctuation analysis was obtained in 24 additional patches. In most cases $(n=18)$, the number of $\mathrm{Na}^{+}$channels, as determined by fluctuation analysis, was equal to the maximal peak current amplitude divided by the unitary current amplitude. However, in the other six patches, all of which contained $>16$ channels, the "traditional" method yielded a lower $N$ value; this suggests that with a large number of channels and a finite series of depolarizations, no single step causes all channels to open simultaneously.

Figure 4 illustrates a series of experiments in which the char- 

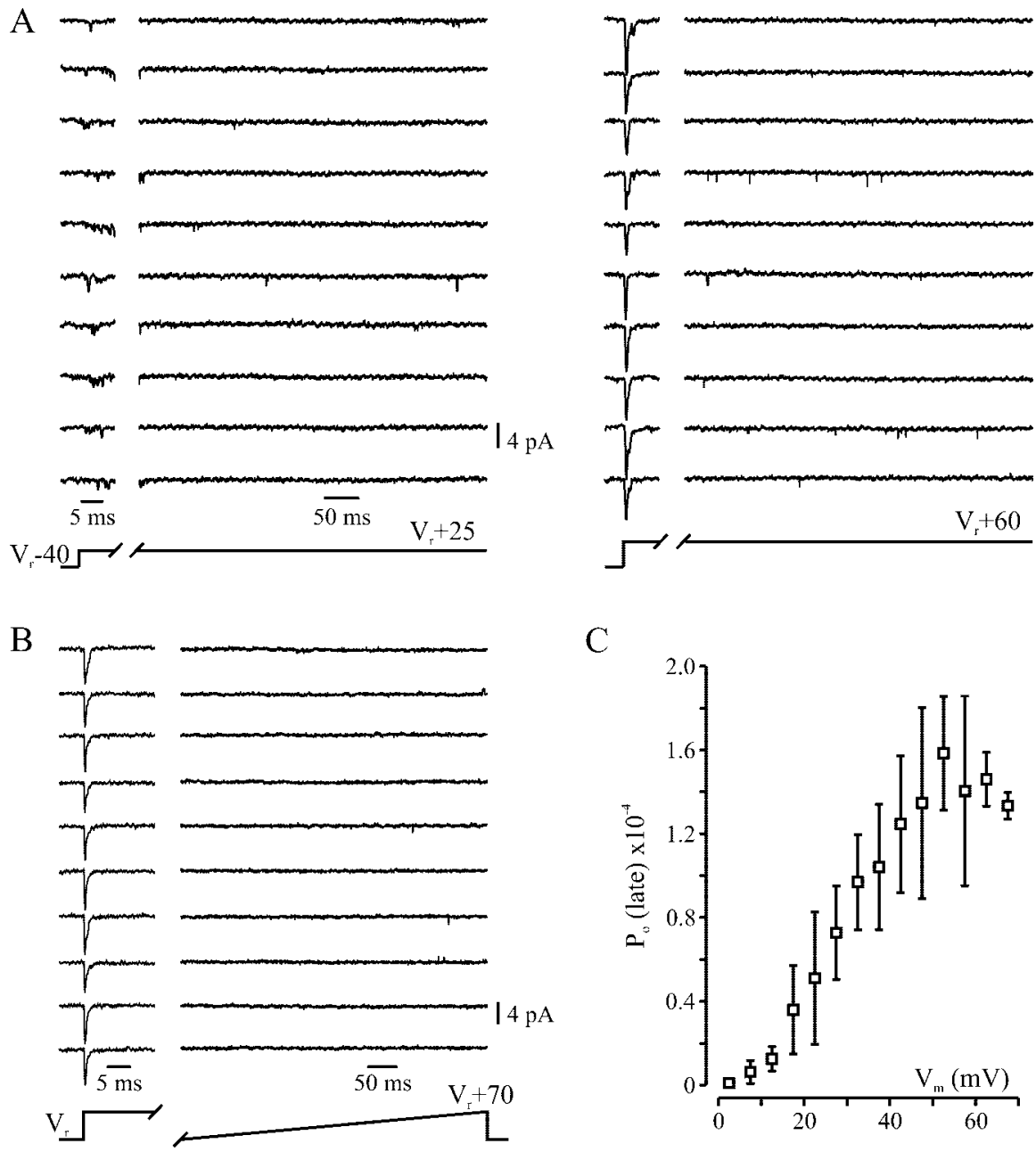

Figure 4. Late $\mathrm{Na}^{+}$channel openings occur rarely in somatic patches at physiological temperature. $\boldsymbol{A}$, In somatic cell-attached recording from a representative neuron, brief late openings are rare and there are no noninactivating gating mode episodes. The patch contained $12 \mathrm{Na}^{+}$channels (as determined by peak current fluctuation analysis; see above). Patch membrane was held at $V_{r}-40 \mathrm{mV}$ and stepped to just suprathreshold voltage of $V_{r}+25 \mathrm{mV}$ (left) or to $V_{r}+60 \mathrm{mV}$ (right) for $500 \mathrm{~ms}$. Channel currents were filtered at $3.5 \mathrm{kHz}(-3 \mathrm{~dB})$ and digitized at $20 \mathrm{kHz}$. Note that, in this patch, approximately one of the channels would have to be persistently open in one of every eight depolarizations for $I_{\mathrm{NaP}} /$ peak $I_{\mathrm{NaT}}$ amplitude ratio to reach $1 \%$ value. $\boldsymbol{B}$, Late somatic $\mathrm{Na}^{+}$channel openings are rare during slow voltage ramps. Ten consecutive current traces recorded from a patch that contained 14 channels under conditions similar to those described for $\boldsymbol{A}$. Transient openings of $\mathrm{Na}^{+}$channels were elicited by $40 \mathrm{~ms}$ depolarizing pulses from $V_{r}$ to $V_{r}+70 \mathrm{mV}$, which were followed by 500 ms ramps from $V_{r}$ to $V_{r}+70 \mathrm{mV}$ to test the probability of late $\mathrm{Na}^{+}$channel openings. Note that, as with step depolarizations, during voltage ramps, late openings of somatic $\mathrm{Na}^{+}$ channel do not accumulate into a significant persistent current component. $C$, Voltage dependence of open probability of $\mathrm{Na}^{+}$ channels during slow voltage ramps ( $n=5$ patches). To obtain the open probability value, the voltage range covered by ramp was divided into 14, 5-mV-wide bins, and the total open time during each bin was divided by the product of bin duration and the number of channels in the patch. Error bars represent SD.

acteristics of late $\mathrm{Na}^{+}$channel openings were studied using 500ms-long depolarizing voltage steps from $V_{\mathrm{r}}-40 \mathrm{mV}$ to a voltage just above the threshold for $\mathrm{Na}^{+}$channel activation $\left(V_{\mathrm{r}}+25\right.$ $\mathrm{mV}$ ) (Fig. $4 A$, left) and to $V_{\mathrm{r}}+60 \mathrm{mV}$ (Fig. $4 A$, right). In previous studies in acutely dissociated neurons (Alzheimer et al., 1993b; Magistretti et al., 1999a) or in 100- $\mu$ m-thick neocortical slices (Alzheimer et al., 1993b) at room temperature, the most prominent form of late $\mathrm{Na}^{+}$channel activity was described as a temporary failure of $\mathrm{Na}^{+}$channels to inactivate. The resultant sustained bursts of openings, commonly interpreted as transient entrance of the channel into a persistent or "noninactivating" gating mode, has been reported to happen in $\sim 1 \%$ of depolarizations (Patlak and Ortiz, 1985; Alzheimer et al., 1993b; Magistretti et al., 1999a) in patches that contain $\sim 4-12$ channels. Surpris- ingly, this phenomenon was never observed in our recordings from $>100,000$ depolarizations and $>500$ patches at physiological temperature. Sporadic, brief, late $\mathrm{Na}^{+}$channel opening, an additional form of late channel activity (Alzheimer et al., 1993b), was observed, albeit rarely, at various times during a sustained depolarization (Fig. 4A). Calculation of the per channel open state probability corresponding to these events gave values of $0.8 \pm 0.3 \times$ $10^{-4}$ for $V_{\mathrm{r}}+25 \mathrm{mV}$ ( $n=10$ patches $)$ and $1.3 \pm 0.5 \times 10^{-4}$ for $V_{\mathrm{r}}+60 \mathrm{mV}(n=14$ patches). This is too low to account for the magnitude of $I_{\mathrm{NaP}}$ in whole-cell recordings. Similar results were obtained in experiments in which late $\mathrm{Na}^{+}$channel openings were studied using 500-ms-long depolarizing voltage ramps from $V_{\mathrm{r}}$ to $V_{\mathrm{r}}+70 \mathrm{mV}$. For example, in the representative patch in Figure $4 B$, which contained $14 \mathrm{Na}^{+}$channels and was held at $V_{\mathrm{r}}$ (approximately $-77 \mathrm{mV}$ ), the incidence of brief late opening during the slow voltage ramps was rare at all voltages, although transient channels openings were seen at the beginning of the depolarizing steps to $V_{\mathrm{r}}+70$, which were applied before each ramp to ensure the stability of the recording and the neuronal resting potential. In the voltage range tested, $P_{\mathrm{o}}$ of the brief late openings followed a Boltzmann-type pattern with a maximum of $1.0-1.4 \times 10^{-4}$ $\left(<0.02 \%\right.$ of maximal $P_{\mathrm{o}}$ of the transient $\mathrm{Na}^{+}$current) at voltages positive to $V_{\mathrm{r}}+$ $45 \mathrm{mV}$ (Fig. 4C).

\section{Axonal origin of $I_{\mathrm{NaP}}$}

The above experiments indicate that the $I_{\mathrm{NaP}}$ evident in whole-cell recordings does not originate at the soma. $\mathrm{Na}^{+}$channels that might give rise to $I_{\mathrm{NaP}}$ are present with more or less uniform density (Stuart and Sakmann, 1994; Colbert and Johnston, 1996; Migliore and Shepherd, 2002) in the membrane of other neuronal compartments, including apical and basal dendrites and the proximal axon. We tested their possible involvement in whole-cell $I_{\mathrm{NaP}}$ by locally applying TTX while recording ramp currents with a somatic whole-cell pipette. To minimize the spread of toxin, we used a TTX concentration of $10^{-7} \mathrm{M}$, which is 10 -fold lower than usual. TTX was delivered to various sites by gentle pressure ejection (5-10 ms pressure pulses of $20 \mathrm{psi}$ ) through a patch pipette with tip diameter of $1 \mu \mathrm{m}$. In a control experiment to estimate the area of toxin spread, glutamate at a concentration of $100 \mu \mathrm{M}$ (to achieve a concentration: $K_{\mathrm{d}}$ ratio similar to that in TTX experiment), when applied under similar conditions, only produced detectable NMDA receptor-mediated current if applied within $20-25 \mu \mathrm{m}$ of the dendritic membrane of the neuron under study. In the representative recording shown in Figure 5A, local application of TTX to the apical dendrite (top trace and image) and to the soma (middle) had little or no effect on $I_{\mathrm{NaP}}$. However, appli- 
A
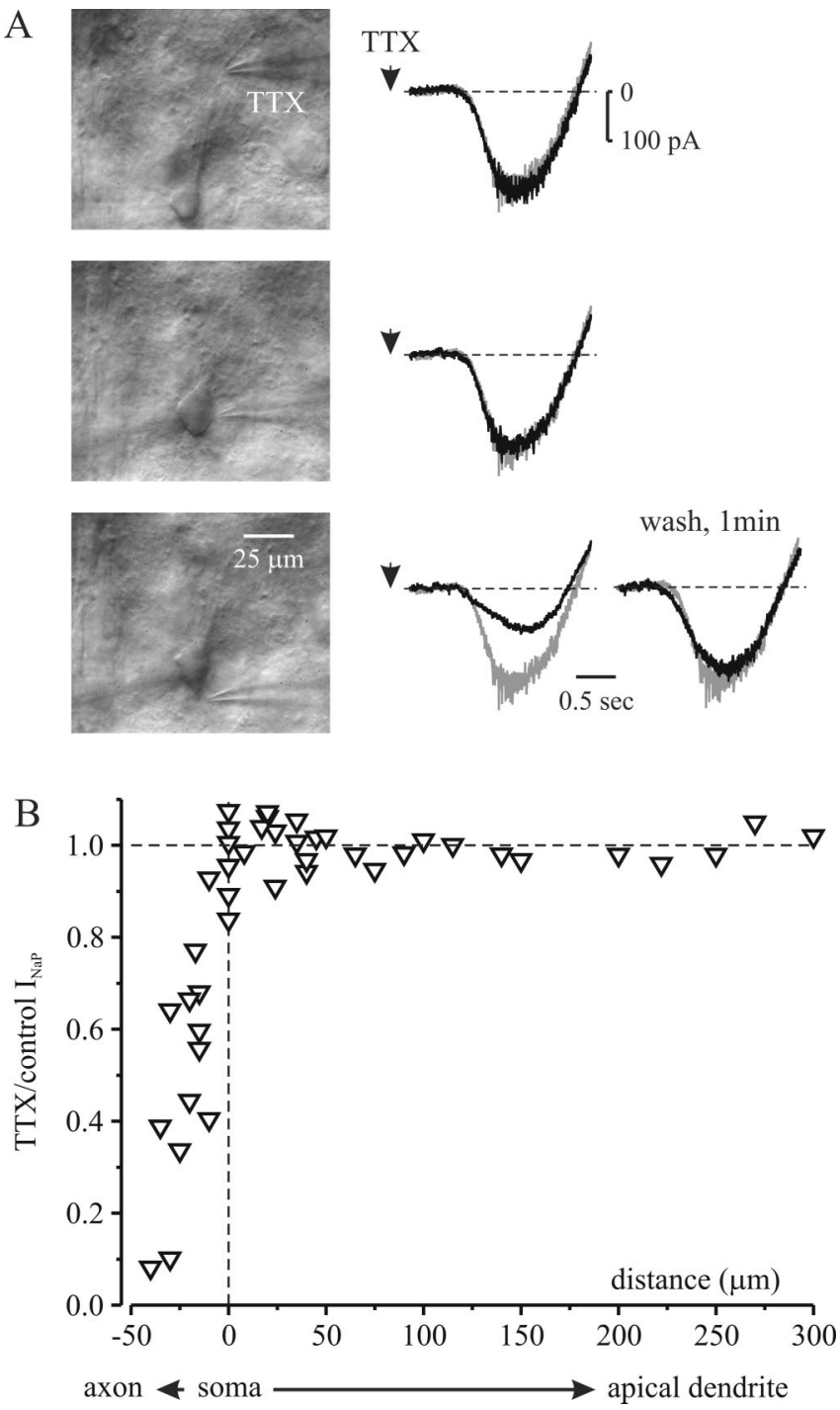

Figure 5. Local application of TTX to the proximal axon blocks whole-cell $I_{\mathrm{NaP}}$, whereas somatic and dendritic applications have little or no effect. $\boldsymbol{A}$, Whole-cell somatic voltage-clamp recording of $I_{\mathrm{Nap}}$ and the effect of application of $0.1 \mu \mathrm{m}$ TTX near the apical dendrite $(75 \mu \mathrm{m})$, near the soma, and near the proximal axon $(-10 \mu \mathrm{m})$. Superimposed are current traces before (gray) and after TTX application (black) at a time indicated by arrow. Currents were elicited by applying the 2-s-long voltage ramps from -70 to $0 \mathrm{mV}$. Note that blockade of $I_{\mathrm{NaP}}$ by TTX applied near the axon was partially reversible. $\boldsymbol{B}$, The graph showing the relative effect of TTX on $I_{\mathrm{NaP}}$ amplitude as a function of application site. The dots are pooled data from nine neurons including that shown in $\boldsymbol{A}$. Each dot represents a ratio of $/_{\mathrm{NaP}}$ amplitude at $-35 \mathrm{mV}$ before and after TTX application.

cation of TTX to the proximal axon of the same neuron rapidly and reversibly blocked $I_{\mathrm{NaP}}$ by $\sim 65 \%$. As evident in the graph in Figure $5 B$, which shows pooled data from the nine experiments in which this protocol was implemented, the same fundamental result was always found: TTX application near the initial portion of the axon, $10-40 \mu \mathrm{m}$ from the soma, caused $I_{\mathrm{NaP}}$ to decrease by as much as $97 \%$, whereas application to the proximal portion of apical dendrite $(<300 \mu \mathrm{m})$ (Fig. $5 B)$ or to the basal dendrites $\left(<70 \mu \mathrm{m}\right.$; data not shown) had no effect on $I_{\mathrm{NaP}}$. In three cells, application directly to the soma caused $I_{\mathrm{NaP}}$ to decrease by $10-$ $15 \%$. In all cases, vertical or lateral movement of the application pipette by $20-25 \mu \mathrm{m}$ completely abolished the TTX effect.

\section{Axonal origin of $I_{\mathrm{NaP}}$ underlying Na plateau potentials}

The simplest interpretation of these observations is that $I_{\mathrm{NaP}}$ is generated by $\mathrm{Na}^{+}$channels located in the proximal axon, with little, if any, participation of somatic and dendritic channels. We therefore performed a series of experiments in which a current clamp manifestation of $I_{\mathrm{NaP}}$, the Na plateau potential (Fleidervish and Gutnick, 1996), was used to test whether its behavior is compatible with a focal, axonal origin for $I_{\mathrm{NaP}}$. Figure $6 \mathrm{~A}$ shows a current-clamp recording from a representative layer 5 neuron in which $\mathrm{K}^{+}$currents were blocked by using $\mathrm{Cs}^{+}$as the main intracellular cation and $\mathrm{Ca}^{+}$currents were blocked by adding $200 \mu \mathrm{M}$ $\mathrm{Cd}^{+}$to the bath. Under these conditions, a brief suprathreshold depolarizing current pulse delivered to the soma (Fig. $6 \mathrm{~A}$ ) or to the dendrite (data not shown) elicited a prolonged, all-or-none Na plateau that persisted after the initial fast spike. As described previously (Fleidervish and Gutnick, 1996), during the plateau, which lasted $0.5-5 \mathrm{~s}$, the gradual decline in membrane potential reflected the changing balance between slowly inactivating $I_{\mathrm{NaP}}$ and $I_{\text {cat }}$. When the plateau reached a value of about $-35 \mathrm{mV}$, regenerative repolarization ensued. The decline of the plateau was usually associated with a crescendo of voltage oscillations (7-25 Hz), which gradually grew to trigger slowly rising action potentials of increasing amplitude (Fig. $6 A, B$ ). In simultaneous, double recordings from soma and proximal apical dendrite $(\sim 300 \mu \mathrm{m})$, the depolarizing envelope of the Na plateau initiated near the soma and spread into the dendrite almost without attenuation (Fig. 6B). This is not surprising considering the electrotonic compactness of a Cs ${ }^{+}$-dialyzed pyramidal cell (apparent input resistance, $1.5 \pm 0.3 \mathrm{G} \Omega ; n=12$ ). Indeed, most of the dendritic tree of a pyramidal neuron perfused with $\mathrm{Cs}^{+}$is probably isopotential for near DC events (Spruston et al., 1994). In contrast, we expect the electrotonic spread of the higherfrequency events, such as oscillations and action potentials, to be constrained by the $\mathrm{Cs}^{+}$dialysis, which causes a significant increase in membrane time constant ( $34 \pm 2 \mathrm{~ms} ; n=12)$. With events generated by a focal current sink, the extent of dendritic filtering and the phase lag are expected to increase with increasing distance from the active region. In eight simultaneous recordings from soma and dendrites (Fig. 6C), the dendritic oscillations were delayed and had lower amplitude than the somatic ones. This accords well with the hypothesis that the $I_{\mathrm{NaP}}$ that provides the inward current for the oscillations is concentrated in the axons, and the oscillation spread passively into the dendrites.

Figure 6, $D$ and $E$, illustrates a different approach to determine the location of the $I_{\mathrm{NaP}}$ sink that underlies the Na plateau. The $\mathrm{Na}$ plateau can be terminated by injecting a hyperpolarizing current pulse whose magnitude and duration are large enough to bring the membrane potential below a critical value (Fig. 6D). In simultaneous recording from soma and dendrite, comparison of the minimal duration of the hyperpolarizing pulse of fixed amplitude that causes a regenerative repolarization (Fig. 6E) revealed that this duration was always shorter at the soma than in the dendrite. Moreover, the apparent voltage threshold of regenerative repolarization was significantly more negative for dendritic injections than for somatic ones (Fig. 6E) $(-69 \pm 8, n=24$ vs $-60 \pm 8 \mathrm{mV}, n=43 ; p<0.01)$. This is a reflection of larger electrotonic distance between the current injection site and the place where $I_{\mathrm{NaP}}$-generating channels are located.

\section{Discussion}

The main conclusion from these data are that the $\mathrm{Na}^{+}$channels responsible for $I_{\mathrm{NaP}}$ generation are primarily located in the axon. Thus, direct TTX application to the proximal axon consistently 

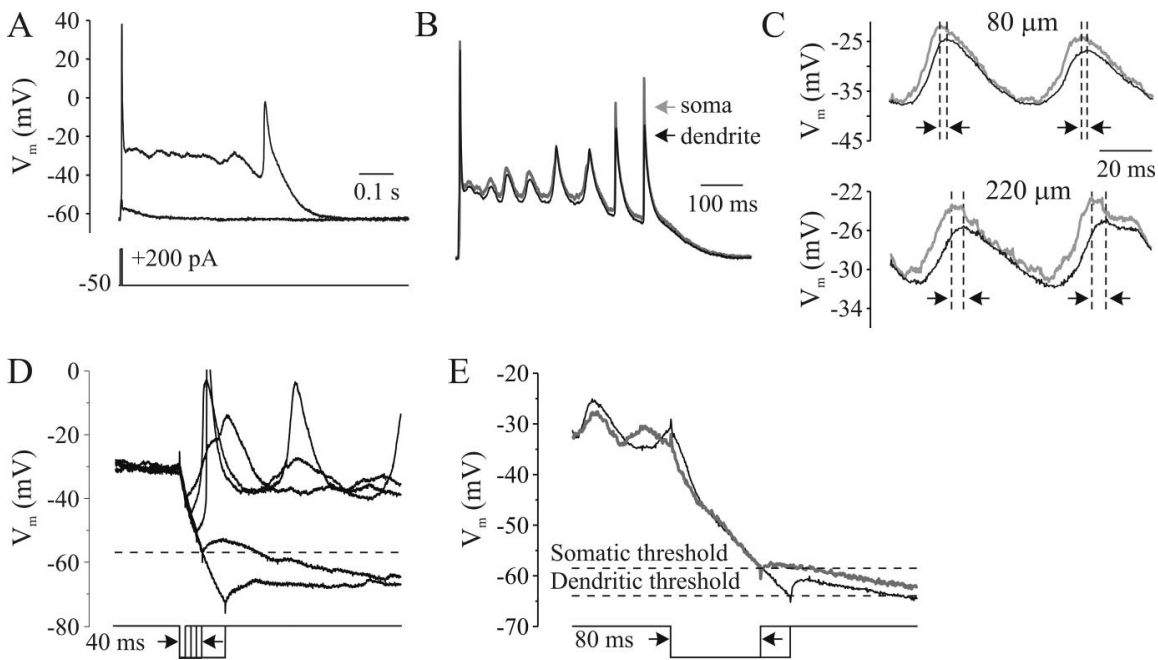

Figure 6. Na plateau potentials are underlaid by axonal $I_{\mathrm{NaP}}$. $\boldsymbol{A}$, Current-clamp manifestation of $I_{\mathrm{NaP}}$ in layer 5 neuron: a prolonged, regenerative Na plateau potential triggered by a brief, just suprathreshold somatic current pulse (10 ms, $200 \mathrm{pA}) . \mathrm{K}^{+}$ currents were blocked by using $\mathrm{Cs}^{+}$as the main intracellular monovalent cation, and $\mathrm{Ca}^{2+}$ currents were blocked by adding 200 $\mu \mathrm{M} \mathrm{Cd}^{2+}$ to the bath. Membrane potential was kept at about $-65 \mathrm{mV}$ by injection of holding current of $-50 \mathrm{pA}$. B, Plateau potentials recorded simultaneously from the soma (thin traces) and the dendrite (thick traces; distance, $80 \mu \mathrm{m}$ ). Note that the slow decline of the plateau is associated with a crescendo of voltage oscillations that grew to trigger action potentials of increasing upstroke velocity and amplitude. C, Voltage oscillations are generated close to soma and spread into dendrites. Two cycles of voltage oscillation recorded simultaneously from the soma (thin traces) and the dendrite (thick traces; distance, $80 \mu \mathrm{m}$ ) to show that the dendritic oscillation is phase-shifted $\left(\sim 16^{\circ}\right)$ and smaller in amplitude compared with the somatic one. In a different pyramidal cell (dendritic recording distance, $220 \mu \mathrm{m}$ ), this phase shift is larger $\left(\sim 30^{\circ}\right)$, consistent with hypothesis that the oscillations initiate around soma and spread passively into the dendrites. D. Hyperpolarizing current pulses ( $120 \mathrm{pA}$ ) of incrementing duration delivered through the somatic pipette during Na plateau, to test the threshold of all-or-none repolarization. Pulses of $>40 \mathrm{~ms}$ were effective, and the voltage threshold, as determined from six trials, was approximately $-58 \mathrm{mV}$. E, Simultaneous recordings from the soma (thin traces) and the dendrite (thick traces; distance, $200 \mu \mathrm{m}$ ) to show that the minimal duration of hyperpolarizing current pulses required to elicit regenerative repolarization is longer in dendrite than in the soma. The apparent voltage threshold of all-or-none repolarization is significantly lower in the dendrite $(-69 \pm 8 \mathrm{mV} ; n=24)$ compared with the soma $(-60 \pm 8 \mathrm{mV} ; n=43 ; p<0.01)$.

blocked $I_{\mathrm{NaP}}$, whereas TTX application on the dendrites did not. When applied to the soma, there was a slight blocking effect in a few cells, which probably reflected toxin spread to the proximal axon. This interpretation is supported by our finding that careful examination of somatic $\mathrm{Na}^{+}$channels did not reveal sufficient late openings to account for the magnitude of somatically recorded persistent current. Finally, simultaneous recordings from soma and apical dendrite revealed that $\mathrm{Na}^{+}$plateau potentials always originate closer to the axon.

Our evidence is based, in part, on whole-cell voltage-clamp recordings of $I_{\mathrm{NaP}}$ elicited by very slow voltage ramps in neurons in which $\mathrm{Cs}^{+}$has replaced $\mathrm{K}^{+}$. It has been suggested that voltage control of neuronal processes may be inadequate with this approach (Cantrell and Catterall, 2001). However, input resistance of $\mathrm{Cs}^{+}$-dialyzed neurons was always $>1 \mathrm{G} \Omega$. A theoretical analysis by Spruston et al. (1994) of attenuation into dendrites of near-DC (but not transient) voltage signals under these conditions predicts satisfactory $(\sim 98 \%)$ control of voltage at distance of up to $1000 \mu \mathrm{m}$ from a somatic pipette.

Although our findings strongly point to the axon as the place where most $I_{\mathrm{NaP}}$ originates, it remains unclear whether this reflects higher channel density, higher probability of late openings of the individual channel, or both. If axonal and somatic channels have the same properties, then the experimentally observed $I_{\mathrm{NaP}}$ magnitude requires the axonal density to be 500-1000-fold higher than the somatic density. Such very high densities have been hypothesized in a theoretical study (Mainen et al., 1995), but they have not been confirmed experimentally (Catterall,
1981; Angelides et al., 1988; Colbert and Johnston, 1996; Colbert and Pan, 2002; Engel and Jonas, 2005). Although channel density in the axon may be or may not be somewhat higher, it seems likely that there is a substantial difference in inactivation properties of axonal $\mathrm{Na}^{+}$channels compared with those in the soma and proximal dendrites. The biophysical and molecular mechanisms of this difference have yet to be elucidated. Our finding that $I_{\mathrm{NaP}}$ amplitude and voltage dependence are not affected by changing the direction of the ramp indicates that the underlying channels truly fail to undergo fast inactivation. This may be caused by "modal" gating (Patlak and Ortiz, 1985; Patlak et al., 1986; Alzheimer et al., 1993b; Brown et al., 1994) or by brief escapes from inactivation during sustained depolarization (Patlak and Ortiz, 1985; Patlak et al., 1986; Alzheimer et al., 1993b). We cannot rule out the possibility that the different propensities of axonal versus somatodendtic channels to generate $I_{\mathrm{NaP}}$ reflects a distinctive channel arrangement relative to intracellular and extracellular matrices (Srinivasan et al., 1998; Qu et al., 1999) or that it is attributable to regional specificity of local regulatory systems (Cantrell and Catterall, 2001). It seems more likely, however, that it is caused by differences in channel subunit composition. Thus, studies in heterologous systems have revealed that the predominately axonal (Caldwell et al., 2000) $\mathrm{Na}_{\mathrm{V}} 1.6$ channels enter the noninactivating gating mode more frequently and produce more persistent current than do channel isoforms localized in soma and dendrites (Raman and Bean, 1997; Smith et al., 1998; Goldin, 2001; Rush et al., 2005).

Our finding that the origin of $I_{\mathrm{NaP}}$ is axonal appears to conflict with the data of Mittmann et al. (1997). These authors used a $\mathrm{Na}^{+}$-sensitive dye to image ion accumulation during $\mathrm{Na}^{+}$plateau potentials in layer 5 pyramidal neurons and found $\mathrm{Na}^{+}$influx in the apical dendrites, which they attributed to $I_{\mathrm{NaP}}$. Although our data do not rule out a small $I_{\mathrm{NaP}}$ in the dendrites, the results of our focal TTX applications indicate that its contribution to the $I_{\mathrm{NaP}}$ we record during slow voltage ramps is relatively insignificant. It is important to note that in addition to $\mathrm{Na}^{+}$channels, there is another route for $\mathrm{Na}^{+}$entry during the $\mathrm{Na}^{+}$plateau, which is not active at subthreshold voltages: the nonspecific $I_{\text {cat }}$. That the membrane potential during the $\mathrm{Na}^{+}$plateau is around $-20 \mathrm{mV}$ reflects a balance between inward $I_{\mathrm{NaP}}$ and outward $I_{\text {cat }}$ (Fleidervish and Gutnick, 1996). Although the molecular identity of the channels that produce $I_{\text {cat }}$ is still unknown, ion substitution experiments have shown it to be permeable to $\mathrm{Na}^{+}$(Alzheimer, 1994). Interestingly, a nonspecific cationic conductance similar to that which underlies $I_{\text {cat }}$ was reported recently in somata, dendrites, and axons of hippocampal pyramidal cells and identified to be dependent on background activation of $\mathrm{Na}^{+}$-permeable channels of the TRP family (Strubing et al., 2001). Activation of dendritic $I_{\text {cat }}$ by the TTX-sensitive $\mathrm{Na}^{+}$plateau could explain the increase in dendritic $\left[\mathrm{Na}^{+}\right]_{\mathrm{i}}$ without dendritic $I_{\mathrm{NaP}}$.

The probability of late openings of somatic $\mathrm{Na}^{+}$channels we find in slices is significantly lower than that of heterologously 
expressed $\mathrm{Na}^{+}$channels (Mantegazza et al., 2005; Rush et al., 2005) and of native $\mathrm{Na}^{+}$channels in the proximal dendrites of isolated stellate cells from entorhinal cortex (Magistretti et al., 1999a,b). The reason for the differences between the different experimental preparations has yet to be elucidated. It might reflect a direct or indirect influence of different experimental manipulations on channel characteristics. For example, we cannot completely rule out the possibility that somatic $\mathrm{Na}^{+}$channels do undergo late openings that are so brief as to go undetected in our recording conditions, yet so prevalent as to underlie $I_{\mathrm{NaP}}$. However, the finding that TTX application to the soma was minimally effective if at all mitigates against this.

It has been shown that under most conditions layer 5 pyramidal neurons are strongly biased to initiate action potentials in the axon rather than in the dendrites, where the EPSP amplitude is largest (Stuart et al., 1997; Waters et al., 2005). Thus, despite the fact that dendrites are excitable, dendritic EPSPs usually generate axonal spikes, which then backpropagate. Thus, the threshold for spike initiation is so much more negative in the axon than in the dendrite that it is still reached first despite EPSP attenuation caused by conduction from a distant site (Stuart et al., 1997). Our findings point to specialized properties of axonal $\mathrm{Na}^{+}$channels, which confer on them a far greater propensity generate $I_{\mathrm{NaP}}$. This is not only helps to establish the axon as the zone of spike initiation, but also directly affects input attenuation by "boosting" EPSPs. The focal axonal presence of large, regenerative subthreshold conductance with voltage and time dependence optimal to manipulate integration of synaptic input, spike threshold, and the pattern of repetitive firing, could provide the pyramidal neurons with a mechanism for dynamic control of their gain. Enhancement or suppression of $I_{\mathrm{NaP}}$ by regulatory systems (Cantrell and Catterall, 2001; Carr et al., 2003; Mantegazza et al., $2005)$ or electrical uncoupling of the axonal $I_{\mathrm{NaP}}$ source from the input areas of the cell by GABAergic inhibition that targets axonal hillock and initial segment (Jones and Powell, 1969) might temporarily shift the spike initiation site and thereby modify integration and output properties of a given pyramidal neuron. Moreover, ectopic appearance of $I_{\mathrm{NaP}}$ in dendrites, attributable, for example, to a $\mathrm{Na}^{+}$channelopathy that affects inactivation (Lossin et al., 2002), might enhance positive feedback within the recurrent cortical circuitry, and thus be epileptogenic.

\section{References}

Alzheimer C (1994) A novel voltage-dependent cation current in rat neocortical neurones. J Physiol (Lond) 479:199-205.

Alzheimer C, Schwindt PC, Crill WE (1993a) Postnatal development of a persistent $\mathrm{Na}^{+}$current in pyramidal neurons from rat sensorimotor cortex. J Neurophysiol 69:290-292.

Alzheimer C, Schwindt PC, Crill WE (1993b) Modal gating of $\mathrm{Na}^{+}$channels as a mechanism of persistent $\mathrm{Na}^{+}$current in pyramidal neurons from rat and cat sensorimotor cortex. J Neurosci 13:660-673.

Andreasen M, Lambert JD (1999) Somatic amplification of distally generated subthreshold EPSPs in rat hippocampal pyramidal neurones. J Physiol (Lond) 519:85-100.

Angelides KJ, Elmer LW, Loftus D, Elson E (1988) Distribution and lateral mobility of voltage-dependent sodium channels in neurons. J Cell Biol 106:1911-1925.

Blanton MG, Lo Turco JJ, Kriegstein AR (1989) Whole cell recording from neurons in slices of reptilian and mammalian cerebral cortex. J Neurosci Methods 30:203-210.

Brown AM, Schwindt PC, Crill WE (1994) Different voltage dependence of transient and persistent $\mathrm{Na}^{+}$currents is compatible with modal-gating hypothesis for sodium channels. J Neurophysiol 71:2562-2565.

Caldwell JH, Schaller KL, Lasher RS, Peles E, Levinson SR (2000) Sodium channel $\mathrm{Na}(\mathrm{v}) 1.6$ is localized at nodes of Ranvier, dendrites, and synapses. Proc Natl Acad Sci USA 97:5616-5620.
Cantrell AR, Catterall WA (2001) Neuromodulation of $\mathrm{Na}^{+}$channels: an unexpected form of cellular plasticity. Nat Rev Neurosci 2:397-407.

Carr DB, Day M, Cantrell AR, Held J, Scheuer T, Catterall WA, Surmeier DJ (2003) Transmitter modulation of slow, activity-dependent alterations in sodium channel availability endows neurons with a novel form of cellular plasticity. Neuron 39:793-806.

Catterall WA (1981) Localization of sodium channels in cultured neural cells. J Neurosci 1:777-783.

Chance FS, Abbott LF, Reyes AD (2002) Gain modulation from background synaptic input. Neuron 35:773-782.

Chandler WK, Meves H (1966) Incomplete sodium inactivation in internally perfused giant axons from Loligo forbesi. J Physiol (Lond) 186:121P-122P.

Colbert CM, Johnston D (1996) Axonal action-potential initiation and $\mathrm{Na}^{+}$channel densities in the soma and axon initial segment of subicular pyramidal neurons. J Neurosci 16:6676-6686.

Colbert CM, Pan E (2002) Ion channel properties underlying axonal action potential initiation in pyramidal neurons. Nat Neurosci 5:533-538.

Crill WE (1996) Persistent sodium current in mammalian central neurons. Annu Rev Physiol 58:349-362.

Cummins TR, Aglieco F, Renganathan M, Herzog RI, Dib-Hajj SD, Waxman SG (2001) Nav1.3 sodium channels: rapid repriming and slow closedstate inactivation display quantitative differences after expression in a mammalian cell line and in spinal sensory neurons. J Neurosci 21:5952-5961.

Engel D, Jonas P (2005) Presynaptic action potential amplification by voltage-gated $\mathrm{Na}^{+}$channels in hippocampal mossy fiber boutons. Neuron 45:405-417.

Fleidervish IA, Gutnick MJ (1996) Kinetics of slow inactivation of persistent sodium current in layer $\mathrm{V}$ neurons of mouse neocortical slices. J Neurophysiol 76:2125-2130.

Fleidervish IA, Friedman A, Gutnick MJ (1996) Slow inactivation of $\mathrm{Na}^{+}$ current and slow cumulative spike adaptation in mouse and guinea-pig neocortical neurones in slices. J Physiol (Lond) 493:83-97.

Fleidervish IA, Binshtok AM, Gutnick MJ (1998) Functionally distinct NMDA receptors mediate horizontal connectivity within layer 4 of mouse barrel cortex. Neuron 21:1055-1065.

Goldin AL (2001) Resurgence of sodium channel research. Annu Rev Physiol 63:871-894.

Gong B, Rhodes KJ, Bekele-Arcuri Z, Trimmer JS (1999) Type I and type II $\mathrm{Na}(+)$ channel alpha-subunit polypeptides exhibit distinct spatial and temporal patterning, and association with auxiliary subunits in rat brain. J Comp Neurol 412:342-352.

Gutnick MJ, Crill W (1995) The cortical neuron as an electrophysiological unit. In: The cortical neuron (Gutnick MJ, Mody I, eds), pp 33-51. New York: Oxford UP.

Haas HL, Schaerer B, Vosmansky M (1979) A simple perfusion chamber for the study of nervous tissue slices in vitro. J Neurosci Methods 1:323-325.

Hamill OP, Marty A, Neher E, Sakmann B, Sigworth FJ (1981) Improved patch-clamp techniques for high-resolution current recording from cells and cell-free membrane patches. Pflügers Arch 391:85-100.

Hammarstrom AK, Gage PW (1998) Inhibition of oxidative metabolism increases persistent sodium current in rat CA1 hippocampal neurons. J Physiol (Lond) 510:735-741.

Hammarstrom AK, Gage PW (1999) Nitric oxide increases persistent sodium current in rat hippocampal neurons. J Physiol (Lond) 520:451-461.

Hodgkin AL, Huxley AF (1952) A quantitative description of membrane current and its application to conduction and excitation in nerve. J Physiol (Lond) 117:500-544.

Huguenard JR, Hamill OP, Prince DA (1989) Sodium channels in dendrites of rat cortical pyramidal neurons. Proc Natl Acad Sci USA 86:2473-2477.

Jones EG, Powell TP (1969) Synapses on the axon hillocks and initial segments of pyramidal cell axons in the cerebral cortex. J Cell Sci 5:495-507.

Kimitsuki T, Mitsuiye T, Noma A (1990) Maximum open probability of single $\mathrm{Na}^{+}$channels during depolarization in guinea-pig cardiac cells. Pflügers Arch 416:493-500.

Lipowsky R, Gillessen T, Alzheimer C (1996) Dendritic $\mathrm{Na}^{+}$channels amplify EPSPs in hippocampal CAl pyramidal cells. J Neurophysiol 76:2181-2191.

Lossin C, Wang DW, Rhodes TH, Vanoye CG, George Jr AL (2002) Molecular basis of an inherited epilepsy. Neuron 34:877-884.

Magistretti J, Ragsdale DS, Alonso A (1999a) High conductance sustained 
single-channel activity responsible for the low-threshold persistent $\mathrm{Na}^{+}$ current in entorhinal cortex neurons. J Neurosci 19:7334-7341.

Magistretti J, Ragsdale DS, Alonso A (1999b) Direct demonstration of persistent $\mathrm{Na}^{+}$channel activity in dendritic processes of mammalian cortical neurones. J Physiol (Lond) 521:629-636.

Mainen ZF, Joerges J, Huguenard JR, Sejnowski TJ (1995) A model of spike initiation in neocortical pyramidal neurons. Neuron 15:1427-1439.

Mantegazza M, Yu FH, Powell AJ, Clare JJ, Catterall WA, Scheuer T (2005) Molecular determinants for modulation of persistent sodium current by G-protein $\beta \gamma$ subunits. J Neurosci 25:3341-3349.

Migliore M, Shepherd GM (2002) Emerging rules for the distributions of active dendritic conductances. Nat Rev Neurosci 3:362-370.

Mittmann T, Linton SM, Schwindt P, Crill W (1997) Evidence for persistent $\mathrm{Na}^{+}$current in apical dendrites of rat neocortical neurons from imaging of $\mathrm{Na}^{+}$-sensitive dye. J Neurophysiol 78:1188-1192.

Neher E, Stevens CF (1977) Conductance fluctuations and ionic pores in membranes. Annu Rev Biophys Bioeng 6:345-381.

Patlak JB, Ortiz M (1985) Slow currents through single sodium channels of the adult rat heart. J Gen Physiol 86:89-104.

Patlak JB, Ortiz M, Horn R (1986) Opentime heterogeneity during bursting of sodium channels in frog skeletal muscle. Biophys J 49:773-777.

Qu Y, Rogers JC, Chen SF, McCormick KA, Scheuer T, Catterall WA (1999) Functional roles of the extracellular segments of the sodium channel alpha subunit in voltage-dependent gating and modulation by betal subunits. J Biol Chem 274:32647-32654.

Raman IM, Bean BP (1997) Resurgent sodium current and action potential formation in dissociated cerebellar Purkinje neurons. J Neurosci 17:4517-4526.

Rush AM, Dib-Hajj SD, Waxman SG (2005) Electrophysiological properties of two axonal sodium channels, Nav1.2 and Nav1.6, expressed in mouse spinal sensory neurones. J Physiol (Lond) 564:803-815.

Smith MR, Smith RD, Plummer NW, Meisler MH, Goldin AL (1998) Functional analysis of the mouse Scn8a sodium channel. J Neurosci 18:6093-6102.
Spruston N, Jaffe DB, Johnston D (1994) Dendritic attenuation of synaptic potentials and currents: the role of passive membrane properties. Trends Neurosci 17:161-166.

Srinivasan J, Schachner M, Catterall WA (1998) Interaction of voltagegated sodium channels with the extracellular matrix molecules tenascin-C and tenascin-R. Proc Natl Acad Sci USA 95:15753-15757.

Strubing C, Krapivinsky G, Krapivinsky L, Clapham DE (2001) TRPC1 and TRPC5 form a novel cation channel in mammalian brain. Neuron 29:645-655.

Stuart G, Sakmann B (1995) Amplification of EPSPs by axosomatic sodium channels in neocortical pyramidal neurons. Neuron 15:1065-1076.

Stuart G, Schiller J, Sakmann B (1997) Action potential initiation and propagation in rat neocortical pyramidal neurons. J Physiol (Lond) 505:617-632.

Stuart GJ, Sakmann B (1994) Active propagation of somatic action potentials into neocortical pyramidal cell dendrites. Nature 367:69-72.

Stuart GJ, Dodt HU, Sakmann B (1993) Patch-clamp recordings from the soma and dendrites of neurons in brain slices using infrared video microscopy. Pflügers Arch 423:511-518.

Taddese A, Bean BP (2002) Subthreshold sodium current from rapidly inactivating sodium channels drives spontaneous firing of tuberomammillary neurons. Neuron 33:587-600.

Waters J, Schaefer A, Sakmann B (2005) Backpropagating action potentials in neurones: measurement, mechanisms and potential functions. Prog Biophys Mol Biol 87:145-170.

Westenbroek RE, Merrick DK, Catterall WA (1989) Differential subcellular localization of the RI and RII $\mathrm{Na}^{+}$channel subtypes in central neurons. Neuron 3:695-704.

Yu FH, Catterall WA (2003) Overview of the voltage-gated sodium channel family. Genome Biol 4:207.

Yue C, Remy S, Su H, Beck H, Yaari Y (2005) Proximal persistent $\mathrm{Na}^{+}$ channels drive spike afterdepolarizations and associated bursting in adult CA1 pyramidal cells. J Neurosci 25:9704-9720. 